\title{
Temperance and the Second-Person Perspective
}

\author{
Andrew Pinsent \\ University of Oxford
}

\begin{abstract}
The virtue of temperance with respect to food and drink is often assumed to be relatively straightforward, a matter of steering a mean between excess and deficiency. Given also that humans share the need to eat and drink with non-human animals, this topic might therefore seem promising to explore for possible connections between evolutionary research on morality and theological ethics. In this paper, however, I argue that many aspects of temperance go far beyond the Aristotelian account and can be understood principally as reflecting the fact that human beings are embodied relational persons. This second-person account can indeed be connected to theological ethics, but it is also one that draws principally from the discontinuities of human and non-human behaviour.
\end{abstract}

\section{Introduction}

The consumption of food and drink is an action that is essential to life and one that human beings share with non-human animals. Given this commonality, the topic of eating and drinking well, dispositions associated with the virtue of temperance, would seem to be a promising one to examine to see if evolutionary research on morality might have any relevance to theological ethics.

There is another reason to focus on temperance with respect to food and drink, namely that it is often supposed to be a relatively straightforward and uncontroversial virtue, to the point that temperance is frequently used as an easy introduction for teaching the meaning of virtue in general. Such 
introductions typically refer, implicitly or explicitly, to Aristotle's Nicomachean Ethics (EN), which Alister MacIntyre has described as the 'canonical text' of virtue ethics. ${ }^{1}$ Aristotle argues that,

Similarly with regard to actions also there is excess, defect, and the intermediate. Now virtue is concerned with passions and actions, in which excess is a form of failure, and so is defect, while the intermediate is praised and is a form of success; and both these things are characteristics of virtue. Therefore virtue is a kind of mean, since it aims at what is intermediate (EN.II.6.1106b23-28). ${ }^{2}$

As is made clear in this text, virtue aims at the intermediate or mean between two vices of excess and deficiency. In the case of temperance, the virtue is the mean between the vices of eating and drinking too much or too little. Moreover, also according to Aristotle, one becomes temperate by doing temperate acts, in other word by habituation, in the manner of learning to play an instrument. ${ }^{3}$ Given that humans and non-human animals will fail to flourish, ultimately to the point of death, by eating too little or too much, and given also that the amount that one tends to eat and drink is at least in part due to habituation, this account of temperance seems straightforward, complete and almost self-evidently correct.

\section{Beyond Aristotle}

Despite the previous assertion, however, it is not difficult to find evidence that temperance is a much more subtle virtue than described above. Moreover, this evidence does not contradict Aristotle, who claims more than once that his account of virtue is intended to be an outline only and by no means complete. ${ }^{4}$ Early Christian commentators on virtue ethics added various refinements. For example, Pope St Gregory I in his influential commentary on the Book of Job at the end of the 6C, added species of gluttony that were later defended by St Thomas Aquinas in his Summa theologiae in the $13 \mathrm{C}{ }^{5}$ These $^{-}$

Alasdair MacIntyre, After Virtue: A Study in Moral Theory, Third Edition, 3rd Edition (Notre Dame, Ind.: University of Notre Dame Press, 2007), 147.

2 Apart from replacing the word "excellence” with "virtue," I have used the translation from Jonathan Barnes, ed., 'Nicomachean Ethics', in The Complete Works of Aristotle, Volume 2: The Revised Oxford Translation, trans. Sir David Ross and James Opie Urmson (Princeton: Princeton University Press, 1984), 1747-48.

3 Nichomachean Ethics [EN] 2.1.1103a31-b1.

4 See, for example, EN 1.7.1098a20-26.

5 ST II-II.148.4, drawing from Gregory, Moralia In Iob. xxx, 18, par. 60. 
species include eating before time, eating too greedily, and inordinate desires for expensive foods or daintily prepared dishes.

The latter point, the gluttony of delicacy, is also highlighted by C. S. Lewis in one of his famous "Screwtape Letters," written in the form of letter from a senior to a junior devil on the best ways of tempting human beings, whom they refer to as their 'patients', to damnation,

... Your patient's mother, as I learn from the dossier and you might have learned from Glubose, is a good example [of the gluttony of delicacy]. She would be astonished - one day, I hope, will be - to learn that her whole life is enslaved to this kind of sensuality, which is quite concealed from her by the fact that the quantities involved are small. But what do quantities matter, provided we can use a human belly and palate to produce querulousness, impatience, uncharitableness, and self-concern? Glubose has this old woman well in hand. She is a positive terror to hostesses and servants. She is always turning from what has been offered her to say with a demure little sigh and a smile "Oh please, please... all I want is a cup of tea, weak but not too weak, and the teeniest weeniest bit of really crisp toast".... At the very moment of indulging her appetite she believes that she is practising temperance. ... The real value of the quiet, unobtrusive work which Glubose has been doing for years on this old woman can be gauged by the way in which her belly now dominates her whole life. ${ }^{6}$

The point to which C. S. Lewis draws attention here is directly relevant to this paper, namely that intemperance is not simply a matter of disordered quantities. Another way in which it is possible to go wrong with respect to food and drink includes that of an exaggerated delicacy in regard to the quality of what one eats and drinks. And this other way of going wrong, in the text above, can have far-reaching and malign effects, not only on the intemperate person but also on those surrounding her.

These examples encourage further examination of the complexity of temperance, especially those customs in regard to eating and drinking that are usually called 'manners.' Manners cover a vast arena

C. S. Lewis, Screwtape Letters: Letters from a Senior to a Junior Devil, C. S. Lewis Signature Classics Edition (London: William Collins, 2012), 87-88. 
of moral choice and, for many people, serve as the central focus of some of their most important training in virtue. ${ }^{7}$ As Margaret Visser writes in her introduction to The Rituals of Dinner,

Table manners maintain and protect taboos and assumptions that seem self-evident within the culture that embraces them. They are rarely discussed, therefore, or even thought about much - until somebody breaks the rules: eats with her mouth open, points at somebody (even at herself) with a knife, spits, grabs other people's food, or is unacceptably guilty of spills. Then the reactions of eating companions are immediate and strong - either outrage ending in hostility, or disgust, which means withdrawal from and rejection of the offender. ${ }^{8}$

As Visser points out in this text, although table manners are not much discussed or even thought about (including, I might add, by most virtue ethicists), they are extremely important. This importance is underlined by the fact that their contravention can have grave social consequences. Moreover, despite some cultural variation and historical development, Visser also observes that,

... table manners, all things considered, are remarkably similar both historically and the world over. There is a very strong tendency everywhere to prefer cleanliness or consideration for others or the solidarity of the dining group. Ritual emphases on such matters are occasionally highly idiosyncratic. But most rituals with these meanings have a good deal in common, and when people do things differently they usually do them for reasons that are easy to understand and appreciate. ${ }^{9}$

In other words, according to this text, even when there are overt differences between cultures, there are underlying commonalities that make the differences comprehensible. This claim suggests that manners have at least some underlying principles that deserve philosophical investigation.

What are these principles? One group of principles concerns the setting. Human persons often plan their meals, a point of distinction between human beings, who dine, and non-human animals, whom we tend to describe, by contrast, as "feeding." 10 Taking a formal meal for a large number of guests as the

7 On an autobiographical note, the first moral lesson I recall was taught to me by my father. Delivered in the third person, I was told that, "If he doesn't say please, he doesn't get the jam." From that time on, initially from a motive of enlightened self-interest, I had to say "Please!" when asking for something at the dining table and then "Thank you!" when receiving the item.

8 Margaret Visser, The Rituals of Dinner: The Origins, Evolution, Eccentricities, and Meaning of Table Manners, 2nd ed. (UK, Canada: Penguin Books Ltd, 2017), xix.

9 Visser, $\mathrm{xix}-\mathrm{xx}$.

10 I am aware that any attempt to articulate a distinction between human and non-human behavior is bound to generate objections, such as references to rare animal behaviors or precursors of human manners. In response I will merely state that some counterexamples in certain ways are not a problem and not the point. The main point, in this paper, is not to define a strict and absolutely exceptionless distinction, in the style of an unbreakable geometric rule, but to articulate differences in an Aristotelian spirit, namely what happens for the most part.

Temperance and the second-person perspective Page 4 
apex exemplar to which most other human meals conform, to a greater or lesser extent, the format of a human meal underlines many other points of distinction. Guests are invited, often to a special room or hall with dedicated furniture, on which places are prepared with specialized tools for eating and drinking. The preparation of the food is usually carried out in a separate place from its consumption, and the manner of its preparation, typically involving cooking and spices, is also a complex and distinctive human practice. The various kinds of food and drink are consumed according to a standard and unfolding order, like a liturgy. On certain occasions, guests will wear special clothes, and the resemblance to a liturgy will be highlighted in some cases by grace at the beginning and possibly also the end of the meal.

There are also principles in regard to how one eats. Despite some minor variations across cultures or when consuming particular foods, the general practice is to lift one's food to one's mouth while maintaining an upright posture. Various specialized tools, collectively called cutlery, have developed to facilitate this process. Even if some cultures and some situations expect or require direct use of the hands, nevertheless the general principle remains of lifting food to one's mouth rather than dropping one's mouth and hence one's whole face into the food. There are also a great many associated taboos, especially against revealing an open mouth containing food. Related to this point, if the persons at table are conversing, which is itself an important and often expected activity, they will also be expected to switch between using their mouths for speaking and for chewing food and strictly to avoid trying to do both at once. ${ }^{11}$ Other taboos include not showing overt greed, or making gesticulations, or filling one's cheeks with food, or spitting, or taking partly chewed food out of one's mouth, or paying attention to anything other than one's fellow diners and the consumables, in that order.

Yet another group of principles is in regard to what we eat. As Visser points out, we typically have an aversion to whatever is slimy in the sense of oozing, slithering, or wobbling, in part, perhaps, due to their resemblance to the residues of organic decay or various bodily excreta; we prefer foods that are either hard or soft rather than indeterminate. ${ }^{12}$ Moreover, as Leon Kass has argued, various other kinds

Visser, 336.

Visser, 338. 
of indeterminacy seem to underpin many of the dietary laws of the eleventh chapter of Leviticus (11:4445). Kass has grouped these exclusions as follows: indeterminacy with respect to place, such as amphibians; creatures that have indefinite form, such as jellyfish, or deceptive forms, such as eels (since they are fish that do not look like fish), or have incomplete forms, like the incompletely cloven-footed animals; creatures that violate proper locomotion, for example by having too many legs (such as centipedes) or no legs at all (such as snakes); or those creatures that violate the original dietary code, especially carnivores. ${ }^{13}$ Most cultures, including Christian cultures, have not been so strict, and indeed there are explicit New Testament passages (such as Acts 10:9-11:18) about the lifting of some of these taboos. Nevertheless, early Christian converts were still instructed to refrain from at least some foods, namely food sacrificed to idols (Acts 15:29), and there is at least one additional taboo that remains very widespread today; except in dire need, one does not eat animals that one has kept as pets.

\section{The Second-Person Perspective}

The considerations above underline the complexity and richness of temperance, if the word is understood as the disposition of eating and drinking well rather than simply finding an Aristotelian mean between consuming too much or too little. But what are the underlying principles that can made sense of this complexity? To make further progress in understanding, it may be helpful to turn to Aquinas's account of virtue ethics, which takes account of many aspects of theological revelation and makes many changes in comparison to the account of virtue ethics in the Nicomachean Ethics.

Although Aquinas wrote a highly regarded commentary on the work of Aristotle, his own massive account of virtue ethics in the Summa theologiae takes a strikingly and unexpectedly different approach. ${ }^{14}$ In most cases, Aquinas does not reject the possibility of habituation or choosing a rational

\footnotetext{
13 Leon R. Kass, The Hungry Soul: Eating and The Perfecting Of Our Nature, New edition (Chicago: University of Chicago Press, 1999), 218-19.

14 ST I-II.55-70; II-II.1-170.
} 
mean of virtue between two extremes of vice. Nevertheless, as I have written extensively elsewhere, ${ }^{15}$ in Aquinas's account the underlying and most important principle in the formation of virtue is a secondpersonal principle, oriented ultimately towards friendship, in which one shares awareness of shared focus with a second person, and one aligns one's stances with that person. ${ }^{16}$

Among adults, phenomena associated with this second-personal relatedness ${ }^{17}$ are commonplace, one of the most well-known instances being mirroring, in which one person subconsciously imitates the gesture, speech pattern, or attitude of a second person. ${ }^{18}$ Among children, or between adults and children, corresponding phenomena are usually described in terms of shared attention or joint attention, and are manifested in a vast range of behaviours, including gaze-following, pointing and following others' points, or reciprocal activities. ${ }^{19}$ In the context of this joint attention, one person's attitudes can be transferred to a second person, a transfer that I have interpreted in terms of what Aquinas refers to as the 'infusion' of the virtues. ${ }^{20}$ Also on this interpretation, second-person relatedness and the forms of the virtues are mutually reinforcing. One may almost be said to catch virtue by aligning and harmonizing with the characteristic stances of those with whom one is relating as 'I' to 'you', and the forms of these infused virtues in turn protect and cultivate second-person relatedness.

Does this principle of second-person relatedness have any bearing on the vast range of customs associated with temperance? On the hypothesis inspired by Aquinas, that second-person relatedness and

15 See Andrew Pinsent, The Second-Person Perspective in Aquinas's Ethics: Virtues and Gifts (New York; Abingdon, UK: Routledge, 2012).

16 The orientation of all the virtues towards friendship is shown, for example, by Aquinas's arguments that love (caritas) is the form of all the true virtues (ST II-II.23.8) and that caritas should be understood principally in terms of friendship (ST II-II.23.1).

17 I use the term 'relatedness' following a recommendation by Peter Hobson, formerly of the Tavistock Clinic in London, since the more familiar term 'relationship' implies depth and duration that are not appropriate for all situations.

18 Tanya L. Chartrand and John A. Bargh, 'The Chameleon Effect: The Perception-Behavior Link and Social Interaction', Journal of Personality and Social Psychology 76, no. 6 (June 1999): 893-910.

19 For an excellent introduction and compilation of papers on this topic, see Naomi Eilan et al., eds., Joint Attention: Communication and Other Minds: Issues in Philosophy and Psychology (Oxford: Clarendon Press, 2005).

20 Andrew Pinsent, 'Who's Afraid of the Infused Virtues? Dispositional Infusion, Human and Divine', in The Virtuous Life: Thomas Aquinas on the Theological Nature of Moral Virtues, ed. H. Goris and H. Schoot (Leuven; Paris; Bristol, CT: Peeters, 2017), 73-96. 
the forms of the virtues are mutually reinforcing, it is important to examine whether and to what extent the observed customs of temperance do indeed have some bearing on second-person relatedness.

One important test case is the common human practice noted previously of lifting one's food and drink to one's mouth. Combined with the maintenance of an upright posture and various taboos, such as those against opening one's mouth when chewing food or filling one's cheeks with food, this practice facilitates face-to-face conversation while dining. These manners therefore protect the integrity and availability of the human face, which plausibly plays an important role in one person relating to another as 'I' to 'you'. An appreciation of this role has been enhanced by the discovery that there are specific neuronal characteristics that are conditions and concomitants for recognizing and interpreting faces. ${ }^{21}$ If these faculties are unavailable, a condition associated with what is called prosopagnosia ("face blindness"), then the person can sometimes be judged as autistic, insofar as second-person relatedness is impeded. ${ }^{22}$ So it is true that those many manners that protect the integrity of the face and its availability for face-to-face interactions are also, in effect, protecting second-person relatedness.

Many of the other manners listed above are also consistent with the priority of the integrity and availability of second-person relatedness. For example, the elaborate business of the setting of meals, with a special time and place, enables many people to gather and the process of eating and drinking to

21 See, for example, Peter Thompson, 'Margaret Thatcher: A New Illusion', Perception 9, no. 4 (1980): 483 - 484; Robert K. Yin, 'Looking at Upside-down Faces', Journal of Experimental Psychology 81, no. 1 (1969): 141-45; G Assal, 'Prosopagnosia', Bulletin de l'Académie nationale de médecine 185, no. 3 (2001): 525-35; discussion 535-536; J. Bodamer, 'Die Prosop-Agnosie', Archiv Für Psychiatrie Und Nervenkrankheiten 179 (1947): 6-53; Martha J. Farah, Karen L. Levinson, and Karen L. Klein, 'Face Perception and Within-Category Discrimination in Prosopagnosia', Neuropsychologia 33, no. 6 (June 1995): 661-74; Winrich A Freiwald, Doris Y Tsao, and Margaret S Livingstone, 'A Face Feature Space in the Macaque Temporal Lobe', Nature Neuroscience 12, no. 9 (September 2009): 1187-96; D I Perrett et al., 'Visual Cells in the Temporal Cortex Sensitive to Face View and Gaze Direction', Proceedings of the Royal Society of London. Series B, Containing Papers of a Biological Character. Royal Society (Great Britain) 223, no. 1232 (22 January 1985): 293-317; Edmund T Rolls, 'The Representation of Information about Faces in the Temporal and Frontal Lobes', Neuropsychologia 45, no. 1 (7 January 2007): $124-43$.

22 Ami Klin et al., 'A Normed Study of Face Recognition in Autism and Related Disorders', Journal of Autism and Developmental Disorders 29, no. 6 (1 December 1999): 499-508, https://doi.org/10.1023/A:1022299920240. Note also that prosopagnosia ('face-blindness') is often manifested by some of the symptoms of autism; see, for example, Kirsten A. Dalrymple et al., 'Developmental Prosopagnosia in Childhood', Cognitive Neuropsychology 29, no. 5-6 (2012): 393-418, https://doi.org/10.1080/02643294.2012.722547. 
become a social engagement. Other manners, such as saying 'please' and 'thank you', provided they are not formulaic and automatic to the point of lacking any conscious attention, acknowledge second persons and can help to avoid treating such persons simply as instruments for obtaining goods.

Many other manners can be interpreted as facilitating second-person relatedness indirectly. For example, taboos against cannibalism are, fairly obviously, rooted in a strong aversion to consuming as food the mortal remains of one to whom one has been relating or could have related as a second person. Moreover, although pets are not typically considered to be actual persons, the kinds of relationships one develops with pets can have some of the characteristics of interpersonal relationships, and hence also there is an aversion to eating the bodies of one's pets. As another example, the gluttony of delicacy, noted previously, promotes disorder in the proper evaluation of goods, at least insofar as it elevates the quality of one's food above gratitude and loving consideration to one's neighbours.

More indirectly, prohibitions against various kinds of unclean or unworthy foods can also be interpreted as protecting second-person relatedness. As Stump has argued in detail in Wandering in Darkness, relations with other persons are inhibited by internal disintegration, as in the doublemindedness of choosing something that one also recognises as wrong in some way; in other words, one can only be integrated internally with oneself and with others by choosing what is good. ${ }^{23}$ Applied to the case of eating and drinking, it seems clear that choosing to consume food that is considered as imperfect or impure will also tend to inhibit second-person relatedness.

These considerations suggest that an extraordinary range of acceptable dispositions in regard to eating and drinking can indeed be accounted for in terms of enabling, encouraging and protecting secondperson relatedness, the kind of relationship of 'I' to 'you' to which most human persons are naturally

23 Eleonore Stump, Wandering in Darkness: Narrative and the Problem of Suffering (Oxford: Clarendon Press, 2010$)$, chap. 7. 
inclined, and the kind of relationship that can also develop, in some cases, into friendship. This claim does not rule out the possibility of other formative influences on temperance. For example, a common aversion to consuming actual or formerly oozing, slithering, or wobbling things may be rooted principally in inherited and prudent instincts to avoid what is potentially harmful. Even in these instances, however, if these dispositions are common, then their violation will also undermine social cohesion, and hence second-person relatedness remains one of the principles that shape temperance.

There is one other important piece of evidence of a strong link between second-person relatedness and dispositions to eat and drink well. I have noted elsewhere that autistic spectrum disorder (ASD) is associated with and may even be specified by reduced or atypical second-person relatedness. What is less well known is that those with serious ASD often have difficulties learning to eat and drink properly, even when they are seriously hungry and thirsty. ${ }^{24}$ This finding is counterintuitive in terms of rationality or animal survival, but it is consistent with the thesis of a very strong link between second-person relatedness and the typical way in which temperance is usually cultivated. Indeed, this link seems so strong that the comparative absence of second-person relatedness may also lead to a dangerous lack of formation of those dispositions to eat and drink that are important for physical survival.

\section{Theological flourishing}

Given that temperance with respect to food and drink seems strongly associated with second-person relatedness to other human persons, what, if any, is the relevance to theological ethics?

One reason for thinking that there may be some relevance is the fact that, in the Judeo-Christian understanding, God is indeed personal in the sense that one can relate to God, by means of divine grace,

24 Brenda Legge, Can't Eat, Won't Eat Dietary Difficulties and Autistic Spectrum Disorders (London; Philadelphia: Jessica Kingsley Publishers, 2002), http://site.ebrary.com/id/10035686. 
as 'I' to 'you' in a way that aligns oneself to God. Perhaps the most famous expression of this relationship in the early Church is the following prayer of St Augustine of Hippo,

Late have I loved you, O Beauty so ancient and so new; late have I loved you! For behold you were within me, and I outside; and I sought you outside and in my ugliness fell upon those lovely things that you have made. You were with me and I was not with you. I was kept from you by those things, yet had they not been in you, they would not have been at all. You called and cried to me and broke open my deafness: and you sent forth your beams and shone upon me and chased away my blindness: you breathed fragrance upon me, and I drew in my breath and do now pant for you: I tasted you, and now hunger and thirst for you: you touched me, and I have burned for your peace. ${ }^{25}$

As I have written elsewhere, the grammar of this prayer, with the constant interplay of 'I' and 'you' forms, and the centrality of the love of God, marks Augustine's text out from the works of pagan antiquity. Certainly, there is nothing remotely like this second-personal prayer in the works of Aristotle, for whom all references to God are in the third person. ${ }^{26}$ But this grammatical interplay is common in Scripture, a central theme of which is the notion of covenant, sometimes described in terms of a spiritual marriage with God. Human flourishing in this context is inherently second-personal with respect to God. Moreover, this conclusion is reinforced by Aquinas's account of virtue ethics, noted previously, in which the primary second-person relationship is with God the Holy the Spirit.

A second reason for thinking that temperance with respect to food and drink has some relevance to the relationship with God is that scripture is replete with references to the existence of some such connection. After all, the description of the fall of humanity and expulsion from Eden near the beginning of the Bible is on account of eating divinely forbidden food (Genesis 3:1-24). Following this

25 Augustine, Confessions 10.27.38, "Sero te amavi, pulchritudo tam antiqua et tam nova, sero te amavi! Et ecce intus eras et ego foris, et ibi te quaerebam, et in ista formosa quae fecisti deformis inruebam. Mecum eras, et tecum non eram. Ea me tenebant longe a te, quae si in te non essent, non essent. Vocasti et clamasti et rupisti surditatem meam; coruscasti, splenduisti et fugasti caecitatem meam; fragrasti, et duxi spiritum et anhelo tibi; gustavi et esurio et sitio; tetigisti me, et exarsi in pacem tuam." The translation is the one used in the contemporary liturgy of the hours of the Catholic Church, The Divine Office: The Liturgy of the Hours According to the Roman Rite (London: Collins, 1974), 225*. The translation used in this reference is a slightly modified version of Augustine, Confessions of St. Augustine, Books I-X, trans. Francis J. Sheed (New York: Sheed \& Ward, 1942).

Pinsent, The Second-Person Perspective in Aquinas's Ethics, 108. 
transgression, God's question, "Where are you?" (Genesis 3:9), is surely about the loss of this relationship 'I' to 'you' rather than God being unable to find the man and woman in space.

Given that the rupture of covenant with God begins, in Scripture, with eating divinely forbidden food, it is not surprising that the restoration of union with God involves sanctified eating. Hence, for example, the first time at which God enjoins the pursuit of holiness, in imitation of his own holiness, is in the text noted previously about dietary laws, namely the eleventh chapter of Leviticus (11:44-45). Hence also it is unsurprising to find that two of the most important actions of the Old and New Testament are in regard to meals. In the Old Testament, the liberation of the Hebrews from slavery is closely associated with the institution of the Passover meal, involving the sacrifice of a lamb without blemish. ${ }^{27}$

In the New Testament, the salvific meal is the Last Supper, the form of which has been incorporated into the central liturgical action of Christianity, the Eucharist:

Now as they were eating, Jesus took bread, and blessed, and broke it, and gave it to the disciples and said, "Take, eat; this is my body." And he took a cup, and when he had given thanks he gave it to them, saying, "Drink of it, all of you; for this is my blood of the covenant, which is poured out for many for the forgiveness of sins. I tell you I shall not drink again of this fruit of the vine until that day when I drink it new with you in my Father's kingdom."28

Whatever else may be said about these words of institution, together with the command "Do this in remembrance of me," (1 Corinthians 11:24), the action in the Eucharist is profoundly interpersonal. On the Catholic understanding of the Mass, the bread and wine become the body, blood, soul, and divinity of Jesus Christ, a special divine action that fulfils literally the prayer of Augustine noted above, "I tasted you, and now hunger and thirst for you." Perhaps even more striking from an interpersonal perspective is that these Eucharistic species are offered in sacrifice, in what can be interpreted as joint attention with the sacrifice of Christ on the cross. In other words, the Mass involves the profoundly second-personal

27 Exodus 12:1-14. See also Kass, The Hungry Soul, 193-231.

28 Matthew 26:26-29; cf. also 1 Corinthians 11:23-24, Mark 14:22-25, Luke 22:13-20, and John 6:22-59. 
action of loving with God what God loves, and sacrificing with God that which God sacrifices, namely the only-begotten Son of God for the salvation of the world. ${ }^{29}$ And the ultimate goal of this sacrifice is to gather humanity to divine life in heaven, one of the most important scriptural metaphors for which is a banquet, as in Revelation 19:9, "Blessed are those who are called to the wedding feast of the Lamb!"

On this account, second-person relatedness in regard to food and drink is not only the principle that underpins a vast range of human manners but is also important for understanding theological claims, including about humanity's relationship with God, the means of salvation, and eternal life. ${ }^{30}$

\section{Concluding remarks}

From these observations, what can be said about the prospects for applying evolutionary research on morality to theological ethics in matters relating to food and drink?

The answer, I think, is that there are some prospects but these are not principally in regard to the physiological needs that humans and non-human animals share in common. Instead, what is most striking in examining the customs of temperance are the profound differences in the ways in which humans and non-human animals consume food and drink. The often tacit but vastly complex rituals that have developed around human consumption manifest, to a greater or lesser extent, our awareness of being embodied relational persons rather than merely animals or even rational animals. Given this background, and the central theme of second-person relatedness to God in the Judeo-Christian tradition, it is not surprising that divinely-appointed rituals in the form of meals, the Passover and Eucharist, should also play such a central role in that tradition. For this reason, any future insights arising from evolutionary

\footnotetext{
29 I am grateful to Rosalind Moss, now Mother Miriam of the Lamb of God, for giving me this idea by means of a talk about the narrative vignette that dispelled her final objections to the Catholic Mass and her conversion to the faith. Mother Miriam asked her listeners to imagine a mother mixing the ingredients for a cake. The mother does not need the help of her young daughter, but. if the little girl is willing to help, the mother does not tell the girl to go away but instead gives the girl a little bowl to mix some of same ingredients beside her.

30 To explore the principle of second-person relatedness further as it impacts on the Christian account of the drama of salvation, I recommend Eleonore Stump, Atonement (Oxford: Oxford University Press, 2018).
} 
research in this field are, I think, be more likely to emerge from a better understanding of the discontinuities rather than the continuities in human and non-human behaviour. ${ }^{31}$

\section{Bibliography}

Assal, G. 'Prosopagnosia'. Bulletin de l'Académie nationale de médecine 185, no. 3 (2001): 525-35; discussion 535-536.

Augustine. Confessions of St. Augustine, Books I-X. Translated by Francis J. Sheed. New York: Sheed \& Ward, 1942.

Barnes, Jonathan, ed. 'Nicomachean Ethics'. In The Complete Works of Aristotle, Volume 2: The Revised Oxford Translation. Princeton: Princeton University Press, 1984.

Bodamer, J. 'Die Prosop-Agnosie'. Archiv Für Psychiatrie Und Nervenkrankheiten 179 (1947): 6-53. Chartrand, Tanya L., and John A. Bargh. 'The Chameleon Effect: The Perception-Behavior Link and Social Interaction'. Journal of Personality and Social Psychology 76, no. 6 (June 1999): 893910.

Dalrymple, Kirsten A., Sherryse Corrow, Albert Yonas, and Brad Duchaine. 'Developmental Prosopagnosia in Childhood'. Cognitive Neuropsychology 29, no. 5-6 (2012): 393-418. https://doi.org/10.1080/02643294.2012.722547.

Eilan, Naomi, Christoph Hoerl, Teresa McCormack, and Johannes Roessler, eds. Joint Attention: Communication and Other Minds: Issues in Philosophy and Psychology. Oxford: Clarendon Press, 2005.

Farah, Martha J., Karen L. Levinson, and Karen L. Klein. 'Face Perception and Within-Category Discrimination in Prosopagnosia'. Neuropsychologia 33, no. 6 (June 1995): 661-74.

Freiwald, Winrich A, Doris Y Tsao, and Margaret S Livingstone. 'A Face Feature Space in the Macaque Temporal Lobe'. Nature Neuroscience 12, no. 9 (September 2009): 1187-96.

Kass, Leon R. The Hungry Soul: Eating and The Perfecting Of Our Nature. New edition. Chicago: University of Chicago Press, 1999.

Klin, Ami, Sara S. Sparrow, Annelies de Bildt, Domenic V. Cicchetti, Donald J. Cohen, and Fred R. Volkmar. 'A Normed Study of Face Recognition in Autism and Related Disorders'. Journal of Autism and Developmental Disorders 29, no. 6 (1 December 1999): 499-508. https://doi.org/10.1023/A:1022299920240.

Legge, Brenda. Can't Eat, Won't Eat Dietary Difficulties and Autistic Spectrum Disorders. London; Philadelphia: Jessica Kingsley Publishers, 2002. http://site.ebrary.com/id/10035686.

Lewis, C. S. Screwtape Letters: Letters from a Senior to a Junior Devil. C. S. Lewis Signature Classics Edition. London: William Collins, 2012.

MacIntyre, Alasdair. After Virtue: A Study in Moral Theory, Third Edition. 3rd Edition. Notre Dame, Ind.: University of Notre Dame Press, 2007.

Perrett, D I, P A Smith, D D Potter, A J Mistlin, A S Head, A D Milner, and M A Jeeves. 'Visual Cells in the Temporal Cortex Sensitive to Face View and Gaze Direction'. Proceedings of the Royal Society of London. Series B, Containing Papers of a Biological Character. Royal Society (Great Britain) 223, no. 1232 (22 January 1985): 293-317.

31 I would like to acknowledge and thank Raymond Tallis and Sir Roger Scruton RIP, at the summer conference of Ian Ramsey Centre in 2013, for encouraging me to explore human distinctiveness in regard to the consumption of food and drink. I would also like to thank Andrea Aguti and Daniele Bertini for the opportunity to speak on the topic of this paper at the University of Urbino in 2018. 
Pinsent, Andrew. The Second-Person Perspective in Aquinas's Ethics: Virtues and Gifts. New York; Abingdon, UK: Routledge, 2012.

. 'Who's Afraid of the Infused Virtues? Dispositional Infusion, Human and Divine'. In The Virtuous Life: Thomas Aquinas on the Theological Nature of Moral Virtues, edited by H. Goris and H. Schoot, 73-96. Leuven; Paris; Bristol, CT: Peeters, 2017.

Rolls, Edmund T. 'The Representation of Information about Faces in the Temporal and Frontal Lobes'. Neuropsychologia 45, no. 1 (7 January 2007): 124-43.

Stump, Eleonore. Atonement. Oxford: Oxford University Press, 2018.

- Wandering in Darkness: Narrative and the Problem of Suffering. Oxford: Clarendon Press, 2010.

The Divine Office: The Liturgy of the Hours According to the Roman Rite. London: Collins, 1974.

Thompson, Peter. 'Margaret Thatcher: A New Illusion'. Perception 9, no. 4 (1980): 483 - 484.

Visser, Margaret. The Rituals of Dinner: The Origins, Evolution, Eccentricities, and Meaning of Table Manners. 2nd ed. UK, Canada: Penguin Books Ltd, 2017.

Yin, Robert K. 'Looking at Upside-down Faces'. Journal of Experimental Psychology 81, no. 1 (1969): $141-45$. 